Grażyna Mikołajczyk-Lerman

(Uniwersytet Łódzki

Instytut Socjologii, Katedra Socjologii Stosowanej i Pracy Socjalnej)

\title{
Warunki i jakość życia w gospodarstwach domowych z dzieckiem niepełnosprawnym
}

\section{Wstęp}

Funkcjonowanie rodziny $\mathrm{z}$ dzieckiem niepełnosprawnym wiąże się z wieloma trudnościami i problemami, które moga powodować zakłócenia w realizacji podstawowych funkcji rodziny. Rodzinie zwykle brakuje wystarczajacego wsparcia instytucjonalnego, a rodzinny kapitał i rodzinne sieci wsparcia nie sa w stanie zaspokoić zwiększonych taka sytuacją potrzeb rodziny. Z. Kawczyńska-Butrym (2008:138) podkreśla, że badania prowadzone wśród rodzin osób niepełnosprawnych wskazują na duże obszary bezradności, na trudności, które przekraczając możliwości tych rodzin, prowadzić moga do ich dysfunkcji. Jednocześnie wiele rodzin deklaruje, że jakoś sobie radza. Często bowiem znajduja się w takiej sytuacji, w której po prostu musza sobie radzić. Członkowie tych rodzin, nie znajdujac wystarczajacej pomocy z zewnatrz, sa skazani albo na wyrzeczenia, rezygnację ze swoich planów życiowych, z kariery zawodowej, z realizacji planów i marzeń oraz na obciążajacca fizycznie i psychicznie wieloletnia mobilizację i powiązany z nia stres, niezależnie od emocjonalnej postawy wobec podjętych i realizowanych zadań opiekuńczych albo na trudna decyzję rezygnacji $\mathrm{z}$ większego zaangażowania w opiekę i szukanie innych rozwiązań.

W każdej z przyjętych opcji występuje ryzyko zaburzeń ich zdrowia fizycznego i psychicznego, zaniedbań w opiece nad osobą niepełnosprawna albo nad innymi osobami z rodziny, a także wystapienia dysfunkcjonalności rodziny, a nawet jej rozpadu.

$\mathrm{Z}$ cała pewnościa, aby pomóc rodzinie osoby niepełnosprawnej należy orientować się zarówno w aktualnych trudnościach tej rodziny, jak też potencjale opiekuńczym.

Do cech charakteryzujących sytuację tych rodzin i możliwości wypełniania ich funkcji można zaliczyć przede wszystkim: strukturę rodziny, 
stan zdrowia pozostałych członków rodziny, dysponowanie czasem na opiekę i pełnione role rodzinne, warunki materialne rodziny, sytuacje mieszkaniowa, sytuacje emocjonalna, więzi, akceptacje i motywacje opieki, a także wiedzę i umiejętności sprawowania opieki nad osobą niepełnosprawną (Kawczyńska-Butrym 2008:139).

W przypadku dzieci niepełnosprawność jest wynikiem wad i schorzeń nabytych we wczesnym okresie życia. Ich stan może ulec poprawie, pozostać bez zmian, ale także ulec pogorszeniu. Bywa, że schorzenie dziecka jest nieodwracalne, choć stopień deficytów zdrowia może ulec zmianie. Przebieg jego dalszego życia będzie uzależniony od tego, jak rodzina i ono samo poradzi sobie ze swoja niepełnosprawnością. Szanse życiowe tych dzieci będą w znaczne mierze zależały od tego, co zdobęda one we wczesnym okresie rozwoju, jakie kompetencje społeczne opanuja i jak rozwina swoje predyspozycje (Bałachowicz 1996; Balcerzak-Paradowska i in. 2002).

$\mathrm{Z}$ tego powodu tak doniosła jest rola rodziny dziecka niepełnosprawnego w zakresie przygotowania go do samodzielnego życia w społeczeństwie na miare jego możliwości. Zły stan zdrowia i niepełnosprawność jest jedna z przyczyn ograniczonej aktywności zawodowej dorosłych i złych materialnych warunków całej rodziny. Ograniczone możliwości rodziny moga spowodować daleko idące konsekwencje dla rozwoju dziecka aktualnie i jego sytuacji w przyszłości. Niepełnosprawność $\mathrm{w}$ dzieciństwie zagraża wykluczeniem społecznym $\mathrm{z}$ edukacji i grona rówieśniczego aktualnie oraz z rynku pracy w dorosłym życiu, a więc także w przyszłości, szczególnie, jeśli dziecko dorasta w niedostatku. Żeby przeciwdziałać temu zagrożeniu niezbędna jest interwencja wspierająca zarówno dzieci i młodzież, jak i ich rodziny. Brak kapitału rodzinnego i możliwości inwestowania w dziecko sprawia, że tylko wsparcie $\mathrm{z}$ zewnatrz (przede wszystkim poprzez odpowiednia pomoc socjalną i adekwatny system edukacyjny) może przerwać tę niekorzystną trajektorię ich życia, a dziecko niepełnosprawne w przyszłości nie będzie niesamodzielnym niepełnosprawnym dorosłym.

\section{Gospodarstwa domowe $\mathrm{z}$ dzieckiem niepełnosprawnym}

Analiza sytuacji gospodarstw domowych z dzieckiem niepełnosprawnym w środowisku wielkomiejskim wskazuje na liczne problemy, z którymi boryka się taka rodzina ${ }^{1}$.

${ }^{1}$ Przedstawione w tekście wyniki badań powstały na postawie analiz materiałów zebranych w trakcie realizacji projektu „Uczeń niepetnosprawny w systemie edukacji. 
Dokonana klasyfikacja badanych według pobieranych przez nich świadczeń umożliwiła podział badanych na kategorie niebiednych $(60,9 \%)$ pobierajacych tylko zasiłek pielęgnacyjny oraz biednych $(39,1 \%)$ pobierajacych zasiłek pielegnacyjny, zasiłek rodzinny (wraz z dodatkiem z tytułu kształcenia i rehabilitacji), świadczenie pielegnacyjne. Dokonanie takiego rozróżnienia umożliwiło analize sytuacji rodzin w zależności od ich statusu materialnego i tym samym ukazało specyfike sytuacji biednego, niepełnosprawnego dziecka. W odróżnieniu od badanych gospodarstw niebiednych, gospodarstwa biednych respondentów, to gospodarstwa, w których rodzice charakteryzuja się niższym wykształceniem, niższa aktywnością zawodowa i częściej sa to rodziny niepełne. W tych gospodarstwach domowych najczęściej wymienianymi problemami sa brak pracy $(25,8 \%)$ i brak pieniędzy na codzienne funkcjonowanie $(36,4 \%)$.

Sytuacja dziecka żyjącego w biedzie jest obarczona ryzykiem dziedziczenia statusu osoby biednej, natomiast gdy dodatkowo jest to dziecko niepełnosprawne, to wtedy ryzyko graniczy prawie $\mathrm{z}$ pewnościa wykluczenia społecznego w przyszłości. Brak realizacji podstawowych praw i zaspokajania potrzeb najmłodszych, i tym samym najsłabszych obywateli powoduje, iż najczęściej biedne dziecko staje się biednym dorosłym, a dziecko niepełnosprawne w przyszłości będzie niesamodzielnym niepełnosprawnym dorosłym.

Dzieci niepełnosprawne sa niejako podwójnie zagrożone: aktualną bieda i wykluczeniem społecznym w przyszłości. Rodzice tych dzieci (często jest to jedyny rodzic) nie moga podjać pracy zarobkowej, gdyż dziecko wymaga całodobowej opieki. Jednocześnie zaś wydatki sa większe niż tam, gdzie dzieci nie wymagają specjalnych lekarstw, dowozów do specjalistów, czy kosztownej rehabilitacji. Wsparcie ze strony

Formy $i$ efektywność pomocy spotecznej świadczonej osobom niepetnosprawnym lub ich opiekunom" realizowanego w ramach projektu naukowo-badawczego Grantu Prezydenta Miasta Łodzi w latach 2009-2010. Podstawe analiz stanowi 601 ankiet przeprowadzonych z rodzicami/opiekunami (547 kobiet i 54 mężczyzn) dzieci niepełnosprawnych w wieku szkolnym oraz 2 wywiady fokusowe $\mathrm{z}$ matkami dzieci niepełnosprawnych, a także treść listów, które dołączane były do ankiet przesyłanych przez rodziców dzieci niepełnosprawnych. Respondentami ankiety byli świadczeniobiorcy takich form wsparcia finansowego, które przysługuja tylko osobom wychowującym niepełnosprawne dziecko (dziecko niepetnosprawne, w znaczeniu niepetnosprawności prawnej, to dziecko, które w trakcie przeprowadzania badania posiadało aktualne orzeczenie o niepełnosprawności lub orzeczenie o stopniu niepełnosprawności). Te świadczenia to: zasiłek pielęgnacyjny, świadczenie pielęgnacyjne, zasiłek rodzinny wraz z dodatkiem z tytułu kształcenia i rehabilitacji dziecka niepełnosprawnego. 
państwa dla tych rodziców jest niewielkie, a w przyszłości rodzice nie będą mieli zasobów finansowych, aby wspierać potomstwo niezdolne do samodzielnego zaspokajania potrzeb bytowych.

\section{Warunki życia rodzin}

Największe problemy pojawiajace się w codziennym funkcjonowaniu rodziny $\mathrm{z}$ dzieckiem niepełnosprawnym przejawiają się głównie w kwestii: aktywności zawodowej rodziców dzieci niepełnosprawnych, sytuacji materialnej i mieszkaniowej rodziny.

Ponad $40 \%$ badanych rodziców dzieci niepełnosprawnych nie pracuje zawodowo. Wśród głównych powodów respondenci wymieniaja przede wszystkim trzy: konieczność opieki nad niepełnosprawnym dzieckiem/ dziećmi, brak możliwości powrotu do pracy, trudności na rynku pracy oraz swoja sytuację zdrowotna (renta, choroba przewlekła, niepełnosprawność). Rodzice obawiają się przede wszystkim o to, że w przyszłości nie mając dochodów i zabezpieczenia finansowego, nie będa mogli wesprzeć swoich niepełnosprawnych i niesamodzielnych dorosłych dzieci, co ilustruja tego typu wypowiedzi:

Najwięcej obaw mam o przyszta emeryture, co będzie z nami takimi matkami, które chowaja - chowaty dzieci specjalnej troski, często sa bez środków do życia. Państwo ubezpiecza matke tylko przez okres 20 lat. Wiek późny matki nie pozwala na prace - a to za stara - wiek okoto 50 lat jest straszny na rynku pracy. A dzieci niepetnosprawne tez sa i będa osobami dorostymi. Niektóre $z$ nich nigdy się nie usamodzielnia. Co $z$ taka matka, która chowata takie dzieci od urodzenia $i$ stan ich zdrowia nie pozwolit na podjęcie żadnej pracy zarobkowej? Tak jak na przyktad ja, od świtu do nocy ciężko przy nich [dzieciach] pracowatam i pracuje $(247)^{2}$.

Złe warunki mieszkaniowe powodują dodatkowe ograniczenia dla dziecka niepełnosprawnego i możliwości jego rozwoju. Potwierdzaja to takie wypowiedzi, jak:

To, że mieszkamy na pierwszym piętrze i rzadko możemy wychodzić $z$ domu, chcemy zamienić mieszkanie i dostosować je tak, by córka mogta bez ktopotu wychodzić $z$ domu oraz korzystać $w$ domu z różnych rzeczy (498).

Mieszkamy $w$ cztery osoby w jednym pokoju $z$ aneksem kuchennym (126/4).

\footnotetext{
${ }^{2}$ Wszystkie cytaty w tekście pochodzące z badań zostały oznaczone numerem ankiety/ wywiadu.
} 
Sytuacja finansowa, warunki mieszkaniowe i stan mieszkania (wilgoć i grzyb) oraz czwarte piętro (543).

Opieka nad dzieckiem niepełnosprawnym wyznacza ramy funkcjonowania „niepełnosprawnej rodziny”, a trudne warunki życia finansowe i mieszkaniowe rodziny oraz brak wsparcia instytucjonalnego przyczyniają się często do dramatycznej sytuacji rodzin, które szukają pomocy i wsparcia, tam gdzie to tylko możliwe:

Bardzo prosze o pomoc mi w sytuacji finansowej, zatatwienie jakiś paczek lub innych rzeczy. Jestem samotna matka, nie mam miejsca zameldowania i mieszkania, stale mieszkam gdzieś indziej, musze się poniewierać. Napisatam do Urzędu Miasta Prezydenta o jakiś lokal, bo nie jestem $w$ stanie z jednej pensji wynajmować dtużej mieszkania, bo mi brakuje pieniędzy na leki, odzież $i$ życie. Nie mam nawet za co zrobić wigilii $i$ świat, bo musze zaptacić za wynajęte mieszkanie. $Z$ dziećmi spałam i mieszkałam $w$ pracy. Mam bardzo ciężka sytuacje, nie mam rodziców ani teściów, bo mi zmarli, ani brata ani siostry. Nie mam do kogo iść z tymi dziećmi. Pisze ten wniosek ze tzami w oczach, bo gdyby nie dzieci, to wolatabym umrzeć, niż tak żyć (233).

Jeżeli chodzi o ocenę wsparcia dla rodzin wychowujących niepełnosprawne dziecko przez badanych, to należy stwierdzić, że dla prawie $60 \%$ ta pomoc jest niewystarczająca. Respondenci w zasadzie sa zgodni, że niewystarczające jest w ich przypadku wsparcie finansowe oraz informacyjne, potęguja to trudności w załatwianiu formalności, biurokracja w instytucjach oraz brak jest możliwości odciążenia rodziców w opiece nad dzieckiem niepełnosprawnym.

W zakresie niewystarczajacego wsparcia finansowego potwierdzaja to takie wypowiedzi:

[Jestem] Pozostawiona $z$ problemami sama sobie. Pogodzenie pracy zawodowej $z$ samotnym wychowaniem dzieci, bez wsparcia finansowego od bytego męza (013).

Zbyt niskie świadczenia socjalne, musiałam zrezygnować $z$ pracy, by opiekować sie synem, wychowywatam go zupetnie sama i nie stać mnie byto nawet na leki dla niego, nie mówiac już o rachunkach bieżacych (535).

Nie moge podjać pracy, a to, co otrzymuje, $z$ trudem wystarcza na leki, pampersy i codzienne wydatki zwiazane $z$ optatami $i$ wyzywieniem (268).

Trudności w załatwianiu formalności oraz biurokrację w instytucjach ilustruja, między innymi takie wypowiedzi rodziców:

Otrzymuja je [wsparcie] ci, którzy tylko „wytrwale zabiegaja”, trzeba pokonać wiele biurokratycznych przepisów (018). 
Brak jakiegokolwiek zainteresowania, chcac cokolwiek zatatwić, zaczynaja sie schody (113).

Rodzice chorych dzieci sa nieraz źle traktowani, sa trudności, żeby coś zatatwić. Momentami sa sytuacje bardzo utrudnione (144).

Ponieważ bardzo trudno ja [pomoc] dostać, potrzeba dużo zaangażowania, trudu - wszyscy robia wielka taske i dostarczanie ciagtych dokumentów, papierków (166).

Niewystarczające wsparcie informacyjne, ilustrują kolejne cytaty:

Ponieważ nigdy nic nie otrzymatam, nie wiem, gdzie mam się zwrócić o pomoc (073).

Każda pomoc jest znikoma oraz mato informacji jest na ten temat (086).

Brak rozpowszechnienia organizacji, które moga pomóc. Wszystko idzie jakby droga pantoflowa (176/7).

Brak możliwości odciążenia rodziców w opiece nad dzieckiem niepełnosprawnym rodzice komentuja w takich przykładowych wypowiedziach:

Największym problemem jest zapewnienie opieki dziecku, kiedy szkoła jest nieczynna, szczególnie w moim przypadku, gdzie jestem jedynym żywicielem rodziny i do pracy muszę iść, brak opieki w wakacje (163/3).

Niewielkim wsparciem dla badanych rodziców dzieci niepełnosprawnych sa także organizacje pozarządowe. Tylko $4,2 \%$ badanych rodziców działa w takiej organizacji pozarządowej pomagającej dzieciom niepełnosprawnym i ich rodzinom.

W świetle wyników przeprowadzonych badań wyraźnie widać, iż najbardziej niedoinwestowani sa najsłabsi, dzieci które są najbardziej poszkodowane zdrowotnie i maja najgorsze warunki do funkcjonowania. Wynika to oczywiście głównie z konieczności większych nakładów na leczenie i rehabilitacje tych dzieci, co ilustruje wypowiedź jednej z matek:

Sa dzieci o większym stopniu niepetnosprawności, wymagajace leków i rehabilitacji, a rodzice nie maja na podstawowe potrzeby (140).

W gospodarstwach niebiednych częściej bowiem podejmowane sa decyzje o „inwestowaniu w dziecko" poprzez dodatkowe odpłatne zajęcia rehabilitacyjne. 


\section{Warunki edukacji i rehabilitacji dziecka niepełnosprawnego}

W świetle przeprowadzonych analiz można wskazać na to, że dziecko niepełnosprawne ma ograniczone perspektywy kształcenia zawodowego. Bariery dyskryminacyjne w procesie edukacji głównie dotyczą dwóch aspektów: braku miejsc w placówkach integracyjnych oraz ograniczenia możliwości kształcenia zawodowego (Mikołajczyk-Lerman 2011b).

Problemy ucznia niepełnosprawnego w systemie edukacyjnym w kontekście ograniczonych perspektyw na przyszłość koncentrują się wokół trudności w dostępie do placówek integracyjnych, specyficznych problemów w szkole i ograniczonych możliwości kształcenia zawodowego.

Rodzice wskazują szczególnie na takie czynniki, które pomogłyby zwiększyć szanse edukacyjne ich dzieci, jak: pomoc szkoły w nadrabianiu zaległości często spowodowanych chorobami dziecka i pobytami w szpitalach, zwiększenie liczby zajęć dodatkowych, zindywidualizowanie podejścia do dziecka niepełnosprawnego, utworzenie większej liczby placówek specjalistycznych dla dzieci niepełnosprawnych i przede wszystkim zwiększenie oferty szkolnictwa zawodowego. Szczególne znaczenie wydaje się mieć dla rodziców stworzenie możliwości kształcenia zawodowego niepełnosprawnych nastolatków, zgodnie z ich możliwościami, ale także z zainteresowaniami. Wśród działań, które mogłyby zwiększyć szanse edukacyjne dziecka niepełnosprawnego, na pierwszym miejscu znalazło się zwiększenie pomocy materialnej $(45,8 \%)$. W dalszej kolejności wymienione są: pozwolić dziecku wykazać się umiejętnościami $(41,3 \%)$ oraz bardziej angażować dziecko w aktywności szkolne (akademie, kółka zainteresowań) (34,4\%).

Rodzice często wskazuja także na brak relacji ich niepełnosprawnego dziecka z rówieśnikami. Szczególnie w wieku dorastania bardzo dolegliwy jest brak kontaktów z kolegami i przyjaciółmi. Niepełnosprawność wraz z przemianami towarzyszacymi adolescencji powoduja zwiększenie poczucia odrzucenia i osamotnienia, co potwierdzaja takie wypowiedzi:

Obecnym problemem mojego dziecka jest wchodzenie w okres dojrzewania. Nie dorównuje swoim rówieśnikom. Jest bardzo zbuntowany, że nie może uczestniczyć $w$ wielu wyjściach, grach grupowych, spotkaniach ze swoimi kolegami (029).

Dziecku wstyd wtasnej niepetnosprawności, odrzucanie przez kolegów (301/7). 
Wśród powodów, dla których dziecko nie będzie kontynuowało nauki najczęściej wymieniane są: zła sytuacja materialna rodziny, problemy z nauka, brak chęci do nauki oraz brak oferty edukacyjnej dla dzieci $\mathrm{z}$ upośledzeniami.

W obliczu tak wielu utrudnień $\mathrm{w}$ warunkach życia rodzin $\mathrm{z}$ dzieckiem niepełnosprawnym, szczególnie rodzin biednych, mało realne wydaje się być zrealizowanie szczególnie oczywistego postulatu podkreślającego fakt, „że szanse niepełnosprawnego dziecka na rozwój i uzyskanie samodzielności życiowej sa znacznie większe (a nierzadko tylko wówczas możliwe) jeśli w proces terapii i edukacji dziecka zaangażowani są rodzice. Nawet najlepsza szkoła nie rozwiąże problemów dzieci niepełnosprawnych bez intensywnej terapii i edukacji podejmowanych $\mathrm{w}$ domu. Konieczne jest, zatem codzienne, trwajace siedem dni w tygodniu, usprawnianie dziecka we własnym domu w oparciu o dobrze przygotowany program obejmujacy wszystkie sfery rozwojowe dziecka: intelektualna, fizyczną i społeczną"3.

Rehabilitacja dziecka niepełnosprawnego często zajmuje większość czasu życia rodziny. Zazwyczaj musi być prowadzona przede wszystkim po to, aby zwiększyć szanse na uzyskanie przez dziecko samodzielności w przyszłości, na miarę jego możliwości.

Trudności, z którymi spotykaja się rodzice dzieci niepełnosprawnych $\mathrm{w}$ zakresie rehabilitacji, wiążą się przede wszystkim z trudnym dostępem do specjalistów, brakiem systematycznych zabiegów i opłatami za usługi rehabilitacyjne. Doświadczenia rodziców ilustruja poniższe wypowiedzi:

W naszym mieście jest kilka instytucji, które powinny pomagać osobom niepetnosprawnym. W rzeczywistości wyglada to zupetnie inaczej, żadnej pomocy, żadnej informacji, żadnego wsparcia, o wszystko trzeba walczyć. Rehabilitacja to walka o każde pót godziny, dziecko niepetnosprawne powinno pracować codziennie, niestety nie należy nam sie codzienna rehabilitacja. Trzeba walczyć, szukać, kombinować. Dla takich dzieci liczy sie kazdy dzień. Z NFZ podobno przystuguje nam rehabilitacja raz na 2 tygodnie 30 minutowa - bardzo przepraszam, ale to sa żarty. Dowiadujac się o niepetnosprawności dziecka zostajemy same. Nikt nas nie informuje o programach pomocy np. auto, komputer. Wszystko trzeba wyszukać saтети (304/0).

Staratam sie o wyjazd moich dziewczynek do sanatorium. Niestety NFZ nie wysyta dzieci $z$ choroba nowotworowa $w$ wywiadzie na leczenie uzdrowiskowe. Moge tylko podziękować „systemowi”. Mam dzieci zbyt chore na

\footnotetext{
${ }^{3}$ Dziennik Urzędowy Ministerstwa Edukacji Narodowej, Warszawa, dnia 15 października 1993 r. (Indeks 355828), nr 9.
} 
to, żeby pojechaty do sanatorium $i$ zbyt zdrowe, żeby jechaty na turnus rehabilitacyjny. Pozostaja nam „tódzkie mury” (150/3).

Żeby cokolwiek kupić dla dziecka, musze zaptacić z wtasnych funduszy, a i tak nie mam pewności, że mi te obiecane pieniadze zwróca (149/7).

Brak dostępu do specjalistów $w$ odpowiednim terminie leczenia. Brak wykonywanych badań na czas. Wizyty przektadane po 6 miesięcy, co powoduje częste postępy chorób bez możliwości zahamowania. Brak dostępu do rehabilitacji (340).

Rodzice wskazują często na konieczność powtarzania uciążliwych procedur, nawet $\mathrm{w}$ przypadku, gdy rokowania w stosunku do zdrowia dziecka wskazują na to, iż stopień deficytów jest nieodwracalny a odzyskanie sprawności niemożliwe.

Moim zdaniem irytujace jest stawanie na komisjach lekarskich co rok, ponieważ wada mojego dziecka nie przestaje istnieć po 12 miesiacach, tylko jest cały czas (121/8).

Starszy syn ma epilepsje, a mtodszy urodzit się z palcozrostem obu dtoni i co roku od nowa sktadatem wnioski o orzeczenie niepetnosprawności (115/3).

\section{Jakość relacji wewnątrzrodzinnych}

Niepełnosprawność dziecka wpływa na wszystkie płaszczyzny życia rodzinnego i oddziałuje, w mniejszym lub większym stopniu, na wszystkich członków rodziny. W prezentowanych badaniach dokonano analizy relacji wewnatrzrodzinnych pod kątem niepełnosprawności dziecka. Wymiar relacji wewnatrzrodzinnych obejmuje relacje z partnerem, relacje między rodzeństwem oraz kontakty z dalszą rodziną, przyjaciółmi i znajomymi.

Struktura badanych rodzin wskazuje, iż ponad $65 \%$ stanowią rodziny pełne (z obojgiem rodziców), w 2,5\% rodzin ojciec odszedł zaraz po narodzinach niepełnosprawnego dziecka, a w przypadku 13,2\% rodzin ojciec odszedł, gdy dziecko było jeszcze małe. W 22,3\% przypadków, gdy rodzice dziecka rozstali się, ojciec niepełnosprawnego dziecka kontaktuje sie z nim, a w przypadku $17,7 \%$ rodzin ojciec tego kontaktu nie utrzymuje, jak relacjonuje jedna z matek: Ojciec dziecka nie widziat go nigdy $w \dot{z} y c i u$ i nie chce go znać (201/7).

W większości rodzin (powyżej 80\%), najwięcej czasu z niepełnosprawnym dzieckiem spędza matka dziecka, w 21,3\% w opiekę włącza się ojciec dziecka (w zależności od tego, czy matka pracuje czy nie - jest 
to mniejsze lub większe zaangażowanie), w co 10 rodzinie w opiekę nad niepełnosprawnym dzieckiem zaangażowane jest rodzeństwo dziecka, a w 13,8\% rodzin opiekę sprawuje także ta osoba, która ma czas (wśród tych osób najczęściej znajdują się dziadkowie, członkowie dalszej rodziny i sasiedzi) (Mikołajczyk-Lerman 2011a).

W rodzinie na tle niepełnosprawności dziecka moga pojawiać się konflikty i nieporozumienia. Wśród badanych $18,1 \%$ wskazuje na konflikty między małżonkami/partnerami, 11,9\% wskazuje na konflikty między niepełnosprawnym dzieckiem a rodzeństwem, 6,9\% na konflikty między matka a dzieckiem pełnosprawnym (częściej występujace w rodzinach, gdzie rodzice maja wykształcenie podstawowe), dokładnie tyle samo na konflikty między ojcem a dzieckiem niepełnosprawnym, a ponad $8 \%$ na konflikty z innymi członkami rodziny (np. dziadkami). Te konflikty najczęściej dotycza podziału obowiązków $(17,1 \%)$, wydatków na niepełnosprawne dziecko $(7,7 \%)$, sposobów wychowania niepełnosprawnego dziecka $(14,4 \%)$ (częściej występują w rodzinach, gdzie rodzice mają wyższe i średnie wykształcenie), czy też przeciążenia rodzeństwa opieka nad dzieckiem niepełnosprawnym (1,6\%).

Wśród aktualnie najważniejszych problemów w gospodarstwie domowym badanych najistotniejsze wydaja się być takie problemy, jak: brak pieniędzy na poważne wydatki $(57,6 \%)$, problemy edukacyjne niepełnosprawnego dziecka (35,7\%), złe warunki mieszkaniowe $(24,0 \%)$, brak pieniędzy na codzienne funkcjonowanie (23,9\%), choroba bliskich (21,5\%), brak pracy $(16,6 \%)$, problemy małżeńskie $(6,7 \%)$, złe stosunki sąsiedzkie $(4,2 \%)$ czy problem alkoholowy w rodzinie $(3,6 \%)$.

Reasumując można stwierdzić, iż trudności w codziennym życiu rodziny z dzieckiem niepełnosprawnym dotycza wszystkich sfer życia małżeńsko - rodzinnego i oczywiście wszystkich członków rodziny, zarówno prokreacji, jak i pochodzenia, co ilustruje między innymi taka wypowiedź: Cała rodzina jest dotknięta niepetnosprawnościa (choroba) dziecka (201/2). Natomiast normalne funkcjonowanie w życiu codziennym jest zaburzone $\mathrm{z}$ powodu często zadawanego sobie przez rodziców pytania: Ktopotem naszym jest pytanie, które $z$ mężem sobie często stawiamy - Co będzie z Jasiem jak nas zabraknie? (200/0).

\section{Postulat zamiast zakończenia}

Choć nie ulega watpliwości, że oferta wsparcia dla rodzin z dzieckiem niepełnosprawnym uległa w ostatnich latach poszerzeniu, brak jest nadal systemowej współpracy pomiędzy instytucjami i organizacjami w tym zakresie, a dzieci z niepełnosprawnościa nie sa traktowane 
priorytetowo w instytucjach rehabilitacyjnych i medycznych. Szczególnie sytuacja jest trudna w biednych gospodarstwach $\mathrm{z}$ dzieckiem niepełnosprawnym. Rodzice tych dzieci zaś sa przekonani, że (...) nasze dzieci sa pokrzywdzone nie tylko przez los, ale też przez nasze Państwo (195/2).

Zbudowanie odpowiedniego i adekwatnego do potrzeb systemu działań jest niezbędne, gdyż pomoc nie może bazować tylko na dobrej woli i zaangażowaniu nauczyciela, urzędnika czy pracownika pomocy społecznej. Należy uczynić wszystko, aby niepełnosprawne dzieci nie stały się w przyszłości dyskryminowanymi biednymi niepełnosprawnymi uzależnionymi od pomocy społecznej. Badacze podkreślają, że nakładające się skutki biedy i niepełnosprawności mogą być dewastujące, gdy występują w dzieciństwie i wczesnej adolescencji. Dlatego też, poprawa warunków materialnych i szans edukacyjnych dzieci niepełnosprawnych powinna znajdować się stale w centrum uwagi władz miasta (Warzywoda-Kruszyńska 2011:16).

Władza lokalna, mająca duże możliwości w zakresie wsparcia dzieci niepełnosprawnych i ich rodzin, powinna inicjować i realizować taka pomoc na wszystkich możliwych szczeblach. W interesie społeczności miejskiej leży przecież, aby niepełnosprawne dzieci nie żyły w przyszłości z zasiłków, ale by mogły funkcjonować samodzielnie na miarę swoich możliwości.

\section{Bibliografia}

Bałachowicz J. (1996), Wychowanie społeczeństwa a integracja osób niepetnosprawnych, [w:] J. Mikulski, J. Auleytner (red.), Polityka społeczna wobec osób niepetnosprawnych. Drogi do integracji, Warszawa.

Balcerzak-Paradowska B., Głogosz D., Kołaczek B. (2002), Dzieci niepetnosprawne - ich miejsce $w$ społeczeństwie oraz możliwości integracji, [w:] B. Balcerzak-Paradowska (red.), Sytuacja osób niepetnosprawnych w Polsce, IPiSS, Warszawa.

Kawczyńska-Butrym Z. (2008), Wyzwania rodziny: zdrowie, choroba, niepetnosprawność, starość, Wydawnictwo Makmed, Lublin.

Mikołajczyk-Lerman G. (2011a), Kobiety $i$ ich niepetnosprawne dzieci, „Acta Universitatis Lodziensis, Folia Sociologica", nr 39, Wydawnictwo Uniwersytetu Łódzkiego, Łódź.

Mikołajczyk-Lerman G. (2011b), Uczeń niepetnosprawny - warunki życia i nauki w opinii rodziców dzieci niepetnosprawnych, [w:] W. Warzywoda-Kruszyńska, G. Mikołajczyk-Lerman (red.), Uczeń $i$ student niepetnosprawny - warunki życia $i$ nauki, Wydawnictwo Biblioteka, Łódź.

Warzywoda-Kruszyńska W. (2011), Niepetnosprawność w dzieciństwie-zagrożenie bieda i wykluczeniem społecznym, [w:] W. Warzywoda-Kruszyńska, G. Mikołajczyk-Lerman (red.), Uczeń $i$ student niepetnosprawny - warunki życia i nauki, Wydawnictwo Biblioteka, Łódź. 


\section{Conditions and quality of life in households with a disabled child}

The functioning of families with a disabled child involves many difficulties and problems, which can cause interference in the implementation of the basic functions of the family. Family usually lack sufficient institutional support, and family capital and family support networks are not able to meet the increased needs of the family situation. The article takes subjects living in households with a disabled child, the quality of life of these families and provide ways to cope with difficulties mainly economic, educational and rehabilitation.

Key words: household, children with disabilities, living conditions, family relations. 